\title{
Rapid restoration of colonic goblet cells induced by a hydrolyzed diet containing probiotics in experimental malnutrition ${ }^{1}$
}

\author{
Restauração rápida de células caliciformes induzida por uma dieta hidrolisada \\ contendo probióticos em desnutrição experimental
}

\author{
Diana Borges Dock-Nascimento ${ }^{2}$, Kelly Junqueira ${ }^{3}$, José Eduardo de Aguilar-Nascimento ${ }^{4}$ \\ 1. Nutrition Scholl and Department of Surgery of the Federal University of Mato Grosso \\ 2. MSc, Assistant Professor, Nutrition Scholl, Federal University of Mato Grosso \\ 3. Nutrition Student, Federal University of Mato Grosso \\ 4. PhD, Full Professor, Department of Surgery, Federal University of Mato Grosso
}

\begin{abstract}
Purpose: To investigate the effects of the addition of probiotic bacteria to a hydrolyzed diet on the recovery of goblet cells during renutrition in an animal model of malnutrition. Methods: Twenty-six male Wistar rats (200-250g) were included in the study. Six were kept under normal conditions (sham group) while twenty received an aproteic diet for 15 days, and were randomized thereafter to receive a hydrolyzed diet containing ( $\mathrm{n}=6$; probiotic group) or not ( $\mathrm{n}=6$; hydrolyzed group) probiotics $\left(10^{6} \mathrm{cfu} / \mathrm{g}\right.$ of Streptococcus thermophilus e Lactobacillus helveticus); or immediately killed ( $\mathrm{n}=8$; aproteic group). Histological slides containing cecal and sigmoid biopsies were used to counting the number of goblet cells and the goblet cells/colonocytes ratio. Results: Malnutrition diminished the population of goblet cells in all sites. Goblet cells/ colonocytes ratio of the probiotic group was significantly greater than hydrolyzed group at the ceccum $(0.39 \pm 0.03 \mathrm{vs}$. 0.34 $\pm 0.02 ; \mathrm{p}=0.02$ ). Only rats fed with probiotics showed complete restoration of the normal goblet cells/colonocytes ratio at the sigmoid ( $0.37 \pm 0,02$ vs. $0.22 \pm 0,03$; $p<0,001)$. Conclusion: Streptococcus thermophilus and Lactobacillus helveticus added to a renutrition diet enhance the recovery of mucocal atrophy induced by malnutrition and especially induce a rapid restoration of goblet cells population in the malnourished colonic mucosa.
\end{abstract}

Key words: Probiotics. Malnutrition. Goblet cell. Mucosa. Colon.

\section{RESUMO}

Objetivo: Investigar os efeitos da adição de probióticos em uma dieta hidrolisada na recuperação de células caliciformes durante a renutriçao em um modelo animal de desnutrição. Métodos: Vinte e seis ratos Wistar (200-250g) foram incluídos no estudo. Seis foram mantidos em condições normais (grupo sham) enquanto que 20 receberam uma dieta aproteica por 15 dias, e foram randomizados para receber uma dieta hidrolisada com (n=6; grupo probiótico) ou sem (n=6; grupo hidrolisado) probióticos $\left(10^{6} \mathrm{cfu} / \mathrm{g}\right.$ of Streptococcus thermophilus e Lactobacillus helveticus); ou foram sacrificados imediatamente ( $n=8$; grupo aproteico). Cortes histológicos contendo biopsias do ceco e sigmoide foram examinados e o número de células caliciformas e a razão caliciformes/colonócitos foram contados. Resultados: A desnutrição diminuiu o número de células caliciformes em todo o cólon. A razão células caliciformes/colonócitos do grupo probiótico foi significantemente maior que o do grupo hidrolizado no ceco ( $0.39 \pm 0.03$ vs. $0.34 \pm 0.02 ; p=0.02)$. Somente os ratos alimentados com probióticos mostrou restauração completa da relação células caliciformes/colonócitos no sigmóide ( $0.37 \pm 0,02$ vs. $0.22 \pm$ 0,03; p<0,001). Conclusão: Streptococcus thermophilus and Lactobacillus helveticus adicionados a uma dieta de renutrição melhora a recuperação da atrofia mucosa induzida pela desnutrição e especialmente induzem a uma rápida restauração da população de células caliciformes na mucosa colônica desnutrida.

Descritores: Probióticos. Desnutrição. Células caliciformes. Mucosa. Colon. 


\section{Introduction}

One of the key functions of the intestine is to prevent lumen bacteria and toxins from reaching systemic circulation, organs or tissues ${ }^{1}$. The intestine is the main immunological organ: it contains $50 \%$ of all reticuloendothelial and other immune cells and it produces the greatest amount of secretory $\operatorname{IgA}^{2}$. The gut flora is one of the main constituents of this defense barrier and is considered the first line of defense of the gut. In fact, failure in this mechanism, results in an increased antigen and toxin transport across the gut mucosa ${ }^{1}$. Protein malnutrition disrupts the normal ecology of microflora ${ }^{3}$ particularly strict anaerobes ${ }^{4}$ and thus producing overgrowth of certain members of harmful flora. Nonspecific mechanisms that include intestinal flora, anatomical barriers (mucosa and epithelium), secretory substances such as lysozymes, IgA, and mucus are affected by malnutrition ${ }^{5}$. Malnutrition induced by dietary restriction produces a series of metabolic changes that lead to a reduction in body weight, depression of immunocompetence and altered of digestive system ${ }^{1}$. These changes have a profound impairment and severe alterations of morphology on variables such as brush border, enzymatic activity, mucosal mass, protein DNA contents and mucosal integrity ${ }^{6-9}$. The injured gastrointestinal mucosal barrier may lead to an increased passage of macromolecules across the intestine ${ }^{7}$. Refeeding rapidly restores the morphology and function of the intestine (repair of the gut atrophy and normalization of intestinal permeability) in rats. The extent of changes depends on the amount of food consumed and quality of dietary nitrogen ${ }^{7,10}$. Hydrolyzed diets, including those containing hydrolyzed proteins as nitrogen source, are frequently used to recover malnourished patients ${ }^{11}$. Tripeptides and dipeptides are more efficiently utilized than free amino acids, have greater nutritional value, are better absorbed, and increase the nitrogen retention than intact protein, contributing to enhance the gain of weight ${ }^{11,12}$. Some organisms as probiotic bacteria have potentially beneficial applications 13, 14. Probiotic bacteria may improve not only the nutritional status and physiology, but also the intestinal microflora, production of IgA, and the immune response 14-16. Probiotic bacteria can be used as innovative tools for treating dysfunctions of the gut mucosal barrier including acute gastroenteritis, food allergy and inflammatory bowel disease ${ }^{14,15}$. The mucus layer component of the intestinal secretion, which is rich in IgA, is produced by mucous-secreting goblet cells. We hypothesized that probiotics may enhance the number of goblet cells during malnutrition recovery. Thus, the aim of the present study was to investigate the effects of the addition of probiotic bacteria to a hydrolyzed diet on the recovery of goblet cells during renutrition in an animal model of malnutrition.

\section{Methods}

Twenty-six male Wistar rats (200-250g) were included in the study. The experiment followed the COBEA guidelines (Brazilian Committee on Experimental Animal Care) adopted by the Federal University of Mato Grosso. Animals were kept in a laboratory environment of light/ dark cycles for three days prior to the experiment. All animals had free access to water.

\section{Induction of malnutrition}

Animals received either a free-protein diet (Rhoster São Paulo, Brazil; composition per $100 \mathrm{~g}, 0.55 \mathrm{~g}$ protein, 88.2g carbohydrate, $7.0 \mathrm{~g}$ lipid, in addition to minerals and vitamins; aproteic group, $\mathrm{n}=20$ ) or a standard rat chow (Rhoster AIN-93, São Paulo, Brazil; composition per 100g: $17.5 \mathrm{~g}$ protein, $67.9 \mathrm{~g}$ carbohydrate, $7.0 \mathrm{~g}$ lipid, in addition to minerals and vitamins; sham group (SG), n=6) for 12 days. Induction of malnutrition after 12 days with this diet was published earlier ${ }^{17}$.

\section{Refeeding after malnutrition}

Eight animals malnourished (aproteic group (AG)) and all six animals of the sham group were killed on the $13^{\text {th }}$ day and necropsied for data collection. After 12 days of malnutrition induction the other 12 rats of the aproteic groups were randomized to two groups to be reefed with either a hydrolyzed diet (20g/day) (composition per $100 \mathrm{~g}$ : 19.96 g protein [80\% dipeptides and 20\% aminoacids], $64.47 \mathrm{~g}$ carbohydrate [ $88 \%$ maltodextrin and $12 \%$ starch], $15.57 \mathrm{~g}$ lipid [50\% mid-chain triglycerids, 30\% milk lipids and $20 \%$ corn oil]; hydrolyzed group (HG), $n=6$ ) or the same diet (16g/day) plus reconstituted milk (4.0g/day) containing $10^{6} \mathrm{cfu} / \mathrm{g}$ of Streptococcus thermophilus e Lactobacillus helveticus (Bionan, Nestlé, Brazil) (final composition per 100g: 18.60g protein, 62.15g carbohydrate, $19.25 \mathrm{~g}$ lipid, probiotic group (PG), $\mathrm{n}=6$ ) for 15 days. Blood samples were collected on the $16^{\text {th }}$ day and then the animals were killed. The two diets were isoenergetic and isonitrogenous. The amount of food consumed was registered daily and the weight was obtained each four days. During necropsy the entire large bowel were dissected, freed from the mesentery, and weighted after the contents were gently removed. Two $\mathrm{cm}$ long full thickness biopsies from cecum (one cm distal to the ileocecal valve) and sigmoid (two $\mathrm{cm}$ above the peritoneal reflexion) were collected and sent for histological analysis in 10\% formalin. Slides containing three or four histological sections of $4 \mu \mathrm{m}$-thick cut sagitally to the mucosa were stained with hematoxylin and eosin, and examined by a experienced blind examiner with an optical microscope (100 X magnification). The number of both goblet cells and colonocytes were obtained in the five best-oriented crypt. The ratio goblet 
cells/colonocytes was calculated in both cecum and sigmoid specimens.

\section{Statistical analysis}

One-way ANOVA or Kruskal-Wallis test followed by Tukey's test was used to compare groups. A 5\% level was established as being statistically significant. Analyses were done using the 11.0 SPSS statistical package.

\section{Results}

Renutrition with either hydrolyzed or hydrolyzed plus probiotics promoted significant increase in the large bowel weights $(p<0.01)$ when compared with aproteic animals. The length of the large bowel did not differ among the groups (Table 1).

\section{Ceccum}

The findings at the ceccum can be seen in Figures 1 and 2. Malnutrition severely diminished the population of goblet cells (14,2 \pm 2 vs. $20 \pm 1$ cells/crypt; $p=0,01)$. After renutrition both diets assured a complete and similar restoration of the goblet cells number at the crypt (control group $=24 \pm 4$ cells/crypt and probiotic group $=23 \pm 6$ cells $/$ crypt; $\mathrm{p}=0,98)$. The ratio goblet cells/colonocytes was significantly compromised with malnutrition. There was a decrease of approximately $31 \%$ in the ratio after the installation of malnutrition $(0.39 \pm 0.01$ vs. $0.27 \pm 0.02$; $\mathrm{p}<$ 0.001 ). Both types of renutrition successfully restored the ratio from malnutrition status. However the goblet cells/ colonocytes ratio of the probiotic group was significantly greater than hydrolyzed group ( $0.39 \pm 0.03$ vs. $0.34 \pm 0.02$; $\mathrm{p}=0.02)$ and similar to non-malnourished animals $(\mathrm{p}=0.98)$.

\section{Sigmoid}

As seen in proximal colon the number of goblet cells/ crypt significantly decrease with malnutrition (26.4 \pm 3.04 vs. $13.4 \pm 4.04$ cells/crypt; $\mathrm{p}<0,01)$. Only rats reefed with probiotics were able to restore the population of goblets cells ( $23.3 \pm 5.18$ cells/crypt; $p=0,04)$. These findings can be seen in figure 3 . The goblet cells/colonocytes ratio decreased with malnutrition ( $0.22 \pm 0,03$ vs. $0.38 \pm 0,01$; $\mathrm{p}=0,001)$. However only rats fed with probiotics showed complete restoration of the normal ratio $(0.37 \pm 0,02$ vs. $0.22 \pm 0,03$; $\mathrm{p}<0,001)$. Animals that received only hydrolyzed diet did not improve goblet cells/colonocytes ratio when compared to aproteic rats $(0.29 \pm 0.08$ vs. $0.22 \pm 0.03 ; \mathrm{p}=0,06)$ (Figure 4$)$.

TABLE 1 - Colonic weight and length in all groups.

\begin{tabular}{|c|c|c|c|c|c|c|}
\hline \multirow[b]{2}{*}{ Variables } & \multicolumn{3}{|c|}{ Groups-Malnutrition phase } & \multicolumn{3}{|c|}{ Groups - Renutrition phase } \\
\hline & $\begin{array}{l}\text { Sham } \\
(n=6)\end{array}$ & $\begin{array}{l}\text { Aproteic } \\
\quad(n=8)\end{array}$ & $p$ & $\begin{array}{c}\text { Probiotic } \\
\quad(n=6)\end{array}$ & $\begin{array}{c}\text { Control } \\
(n=6)\end{array}$ & $p$ \\
\hline Large bowel weight (g) & $1,8 \pm 0,2$ & $1,5 \pm 0,2$ & 0.03 & $2,2 \pm 0,4^{*}$ & $2,3 \pm 0,4^{*}$ & 0.83 \\
\hline Large bowel length (cm) & $20,0 \pm 0,7$ & $19,0 \pm 1,7$ & 0.42 & $19,7 \pm 0,7$ & $20,6 \pm 1,2$ & 0.21 \\
\hline
\end{tabular}

Data express mean \pm SD for the number of rats shown in parentheses. $p$ values of comparisons between 2 groups in each phase. *, $\mathrm{p}<0.01$ vs. Aproteic group (ANOVA followed by Tukey’s test)

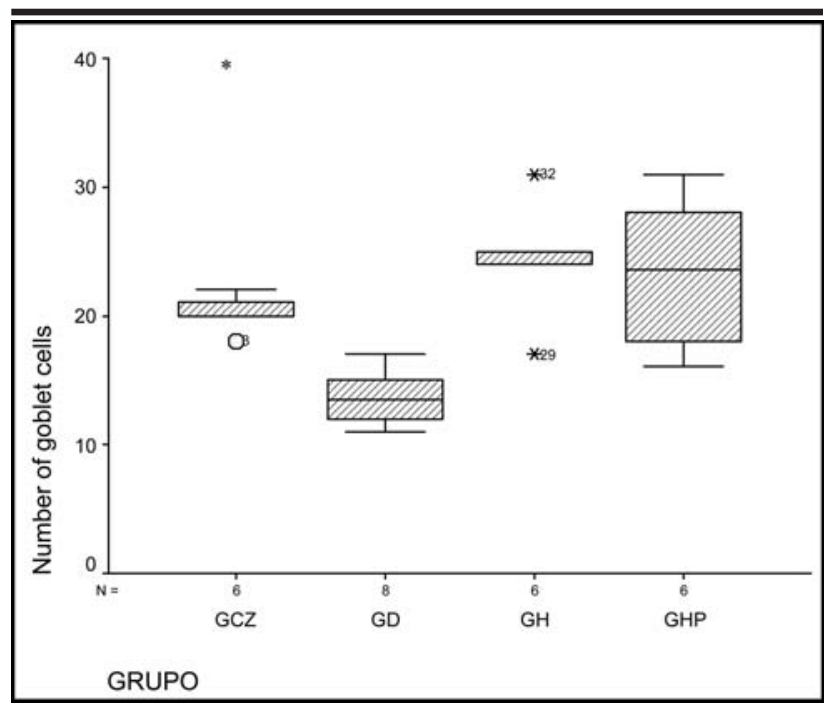

FIGURE 1 - Number of goblet cells per crypt at the ceccum in the four groups. GCZ=sham group; $\mathrm{GD}=$ aproteic group; $\mathrm{GH}=$ hydrolyzed group; GHP=probiotic group. ${ }^{*}=\mathrm{p}<0.01$ vs. GD

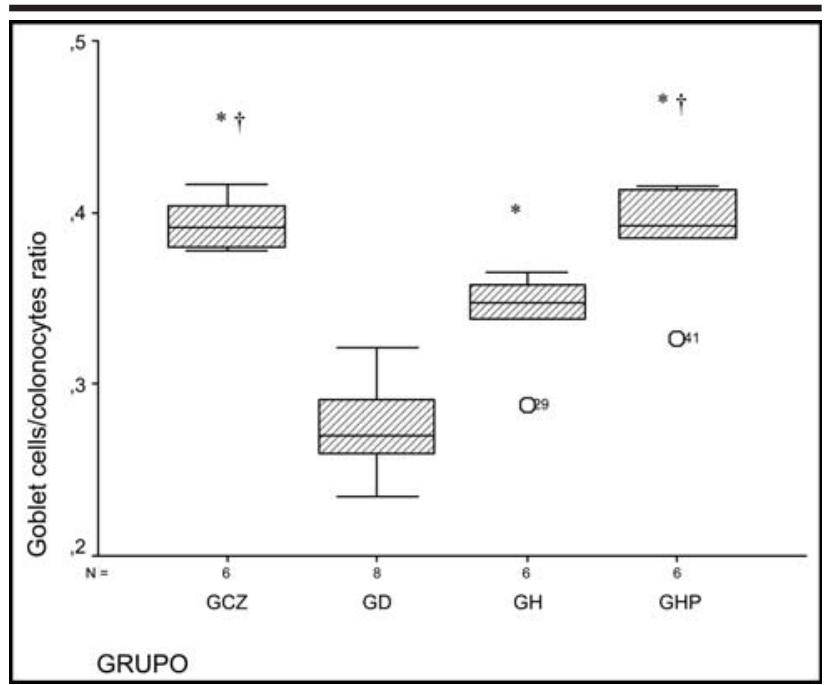

FIGURE 2 - Goblet cells/colonocytes ratio at the ceccum in the four groups. GCZ=sham group; $\mathrm{GD}=$ aproteic group; $\mathrm{GH}=$ hydrolyzed group; $\mathrm{GHP}=$ probiotic group. ${ }^{*}=\mathrm{p}<0.01$ vs. GD; $\dagger=\mathrm{p}$ $<0.001$ (GCZ) е $\mathrm{p}=0.02$ (GHP) vs. GH. 


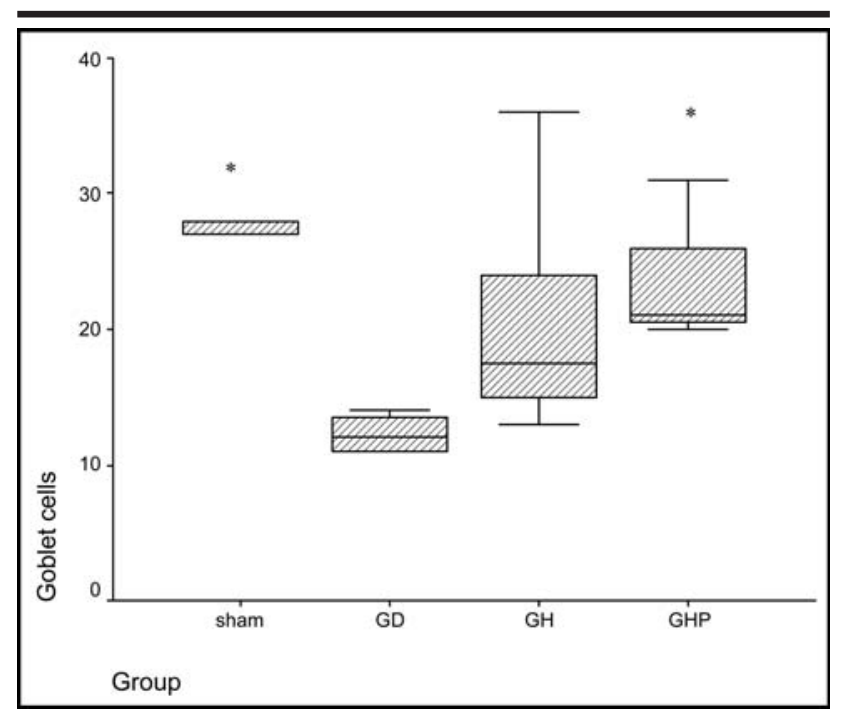

FIGURE 3 - Number of goblet cells per crypt at the sigmoid in the four groups. GCZ=sham group; $\mathrm{GD}=$ aproteic group; $\mathrm{GH}=$ hydrolyzed group; GHP=probiotic group. * $=\mathrm{p}<0.01$ vs. GD

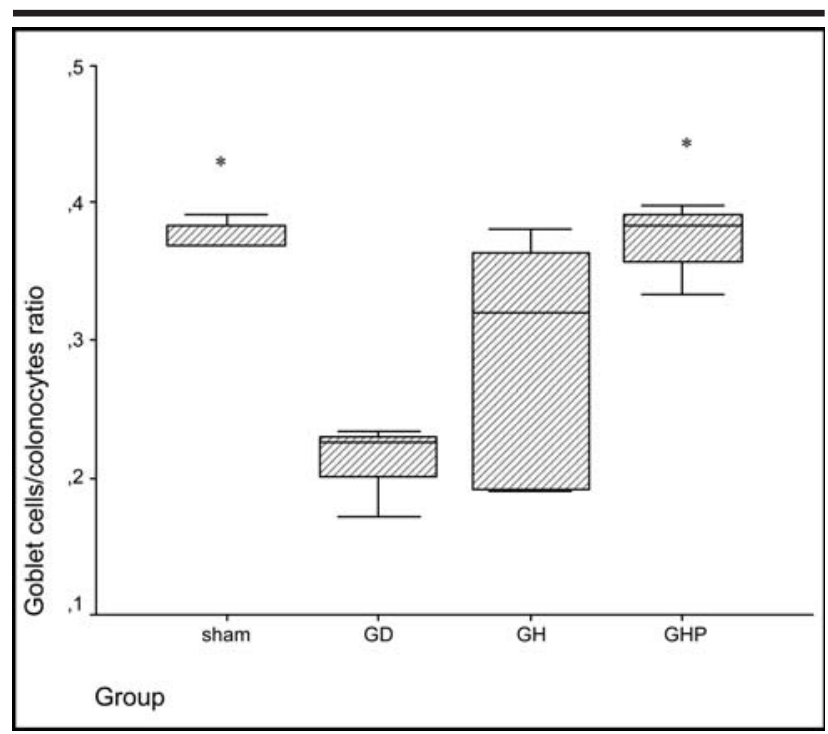

FIGURE 4 - Goblet cells/colonocytes ratio at the sigmoid in the four groups. GCZ=sham group; $\mathrm{GD}=$ aproteic group; $\mathrm{GH}=$ hydrolyzed group; GHP=probiotic group. $*=p<0.01$ vs. GD

\section{Discussion}

The findings of this present study have clearly confirmed that malnutrition diminishes the number of globlet cells at both the cecal and sigmoid sites. The data well demonstrated that only the administration of probiotic bacteria was able to restore the goblet cells/ colonocytes ratio in both large bowel sites. This suggests that probiotics may influence the production of goblet cells by the crypt and thus promote a more rapid colonic mucosal trophism. Nutrition plays a key role in maintaining the balance of the intestinal microflora, and malnutrition disturbs the ecological barrier, and induces histological damage ${ }^{1}$. The production of mucin is decreased in the malnourished gut mucosa ${ }^{5}$. This reduction in mucin concentration is related to the decreased number of goblet cells, is selective, and did not reflect all surface glycoproteins ${ }^{5}$. Some recent reports have consistently attested that probiotics may enhance and accelerate intestinal mucosal trophism ${ }^{1,15,16}$. Our findings showed that probiotics produce a more rapid restoration of goblet cells at the large bowel crypts. This effect produced by probiotics was seen earlier by Cano et $\mathrm{al}^{15}$. The innate immune system plays a crucial role in maintaining the integrity of the intestine and protecting the host against a vast number of potential microbial pathogens from resident and transient gut microflora ${ }^{18,19}$. The innate immune system at the gut mucosa not only provides the first line of defense against pathogenic microorganisms but also provides the biological signals that instruct the adaptive immune system to elicit a response ${ }^{20}$. Probiotics may stimulate the gut innate immune system ${ }^{18,19,21}$. The mechanisms by which probiotic bacteria affect the immune system are unknown

yet, but many of them are attributed to an increase in the innate or in the acquired immune response ${ }^{21}$. Consistent with this argument, probiotic bacteria can stimulate the production of $\operatorname{IgA}^{22,23}$. The overall results suggest that probiotics may enhance mucosal trophism and especially increase the number of goblet cells at the crypt site. As goblet cells are the main mucus producing cells, and mucus is rich in $\operatorname{IgA}^{24}$, we can speculate that probiotics may enhance the local immune system response during renutrition. Although the findings an experimental study should be transposed to the clinical setting with caution it could be concluded that Streptococcus thermophilus and Lactobacillus helveticus added to a renutrition diet enhance the recovery of mucocal atrophy induced by malnutrition and especially induce a rapid restoration of goblet cells population in the malnourished colonic mucosa. Immediate clinical application of this would be the improvement of the gut immune response to pathogenic microorganisms.

\section{References}

1. Allori C, Aguero G, de Ruiz Holgado AP, Nader OM, Perdigon G. Gut mucosa morphology and microflora changes in malnourished mice after renutrition with milk and administration of Lactobacillus casei. J Food Prot. 2000; 63: 83-90.

2. Hulsewe KWE, van Acker BAC, von Meyenfeldt MF, Soeters PB. Nutritional depletion and dietary manipulation: effects on the immune response. World $\mathrm{J}$ Surg. 1999; 23: 536-44. 
3. Tannock GW, Savage D. Influences of dietary and environment stress on microbiological populations in the murine gastrointestinal tract. Infect Immunol. 1974; 9: 591-8.

4. Poxton I, Brown A, Sawyer A, Fergunson A. The mucosal anaerobic gram negative bacteria of the colon. Clin Infect Dis. 1997; 25 (Supl 2): 111-3.

5. Sherman PJ, Forstner N, Roomi I, Forstner G. Mucin depletion in the intestine of malnourished rats. Am J Physiol. 1985; 248:481-3.

6. Firmansyah A, Suwandito L, Penn D, Lebenthal E. Biochemical and morphological changes in the digestive tract of rats after prenatal and postnatal malnutrition. Am J Clin Nutr. 1989; 50:261-8.

7. Poullain MG, Cezard JP, Marche C, Macry J, Roger L, Grasset E, Broyart JP. Effect of dietary whey proteins, their peptides or amino-acids on the ileal mucosa of normally fed and starved rats. Clin Nutr. 1991; 11:48-53.

8. Nunez MC, Bueno JD, Ayudart MV, Almendros A, Rios A, Suarez MD, Gil A. Dietary restriction induces biochemical and morphometric changes in the small intestine of nursing piglets. J Nutr. 1996; 126:933-44.

9. Ortega MA, Nunez MC, Suarez MD, Gil A, SanchezPozo A. Age-related response of the small intestine to severe starvation and refeeding in rats. Ann Nutr Metab. 1996; 40:351-8.

10. Poullain MG, Cezard JP, Roger L, Mendy F. Effect of whey protein, their oligopeptides hydrolysates and free amino acids mixture on the growth and nitrogen retention in fed and starved rats. Parent Enteral Nutr. 1989; 13:382-6.

11. Lochs H, Dejong C, Hammarqvist F, Hebuterne X, LeonSanz M, Schutz T, van Gemert W, van Gossum A, Valentini L; DGEM (German Society for Nutritional Medicine); Lubke H, Bischoff S, Engelmann N, Thul P; ESPEN (European Society for Parenteral and Enteral Nutrition). ESPEN Guidelines on Enteral Nutrition: Gastroenterology. Clin Nutr. 2006; 25:260-74.
12. Zaloga GP, Ward KA, Prielipp RC. Effect of enteral diets on whole body and gut growth in unstresses rats. Parent Enteral Nutr. 1991; 15:42-7.

13. Fuller RA. A review: probiotics in man and animals. J Appl. Bacteriol. 1989; 66: 365-78.

14. Donohue DC. Safety of probiotics. Asia Pac J Clin Nutr. 2006;15:563-9.

15. Cano PG, Aguero G, Perdigon, G. Adjuvant effects of Lactobacillus casei added to a renutrition diet in a malnourished mouse model. Biocell. 2002; 26:35-48.

16. Isolauri E, Juntunen M, Rautanen T, Sillanaukee P, Koivula T. A human Lactobacillus strain (Lactobacillus GG) promotes recovery from acute diarrhea in children. Pediatrics. 1991; 88: 90-7.

17. Dock DB, Aguilar-Nascimento JE, Latorraca MQ. Enhanced immunological response influenced by probiotics during the recovery of experimental malnutrition. Rev Bras Nutr Clin. 2003; 18:157-62.

18. Muller CA, Autenrieth IB, Peschel A. Innate defenses of the intestinal epithelial barrier. Cell Mol Life Sci. 2005;62:1297-307.

20. Nochi T, Kiyono H. Innate immunity in the mucosal immune system. Curr Pharmacol Des. 2006; 12:4203-13.

21. Galdeano CM, Perdigon G. The probiotic bacterium Lactobacillus casei induces activation of the gut mucosal immune system through innate immunity. Clin Vaccine Immunol. 2006; 13:219-26.

22. Kaila M, Isolauri E, Soppi E, Virlanen E, Laine S, Arvilommi $\mathrm{H}$. Enhancement of the circulating antibody secreting cell response in human diarrhoea by a human Lactobacillus strain. Pediatr Res. 1992; 32:141-4.

23. Aguilar-Nascimento JE, Prado S, Zaffani G, Salomao AB, Neves JD, Dock-Nascimento DB, Mello PR, Okay TS. Perioperative administration of probiotics: effects on immune response, anastomotic resistance and colonic mucosal trophism. Acta Cir Bras. 2006 ;21 (Supl 4):80-3.

24. Swank GM, Deitch EA. Role of the gut in multiple organ failure: bacterial translocation and permeability changes. World J Surg. 1996; 20:411-7.

\section{Correspondence:}

José Eduardo de Aguilar-Nascimento

R. Estevão Mendonça, 81/801

78045-200 Cuiabá-MT Brazil
Conflict of interest: none Financial source: none 